\title{
PSYCHOMETRIC QUALITY OF THE GRATITUDE QUESTIONNAIRE IN FILIPINO COLLEGE STUDENTS
}

\author{
Ian Llenares and Cindie Almeda \\ National University (Philippines)
}

\begin{abstract}
This study aims to adapt the Gratitude Questionnaire (GQ-6) to the Philippines, gathering evidence of its validity and reliability. Two studies were conducted. Participants in Study 1 were 340 college students (Mage= 20.63;62.1\% female), who completed the GQ-6 and demographic questions. The exploratory factor analysis was performed, indicating a one-factor solution $(\alpha=.80)$. Participants in Study 2 were 813 college students ( $M$ age $=19.99$ years; 50.1\% male), who answered the GQ-6, the Life Orientation Test-Revised, the Subjective Happiness Scale, and the Spirituality/Religiousness items. Results corroborated the one-factor structure (e.g., $C F I=.98, \mathrm{RMSEA}=.05)$ showing evidence of its association with life orientation $(r=.29)$, subjective happiness $(r=.08)$, and religiosity $(r=.31)$. The scores from the GQ-6 also exhibited invariance across gender. In conclusion, the GQ-6 provide evidence of factorial and criterion validity and reliability, justifying its use in the Philippines.

KEY WORDS: gratitude, positive psychology, validity, reliability.
\end{abstract}

\section{Resumen}

El objetivo de este estudio fue adaptar el "Cuestionario de gratitud" (GQ-6) a Filipinas, recogiendo pruebas sobre su validez y fiabilidad. Se realizaron dos estudios. En el estudio 1 participaron 340 estudiantes universitarios ( $M_{\text {edad }}=20,63$ años; $62,1 \%$ mujeres), que contestaron el GQ-6 y los datos sociodemográficos. El análisis factorial exploratorio mostró una solución de un factor $(\alpha=0,80)$. En el estudio 2 participaron 813 estudiantes universitarios (Medad=19,99 años; 50,1\% hombres), que respondieron el GQ-6, el "Test revisado de orientación a la vida", la "Escala de felicidad subjetiva" y los ítems sobre espiritualidad/religiosidad. Los resultados confirmaron la estructura unifactorial del GQ-6 (p. ej., CFI= 0,98, RMSEA $=0,05)$ mostrando evidencia de su asociación con la orientación a la vida $(r=0,29)$, la felicidad subjetiva $(r=0,08)$ y la religiosidad $(r=0,31)$. Las puntuaciones del GQ-6 mostraron invariancia de sexo. En conclusión, el GQ-6 proporciona pruebas de validez y fiabilidad factorial y de criterio, lo que justifica su uso en Filipinas.

PALABRAS CLAVE: gratitud, psicología positiva, validez, fiabilidad. 


\section{Introduction}

Research on the promotion of healthy individual flourished as positive psychology introduced (Fredrickson, 2001; Seligman, 2012; Seligman \& Csikszentmihalyi, 2014). Advancing our knowledge on understanding human potentialities, strengths, and well-being should be our first priority (Fredrickson, 2000; Peterson \& Seligman, 2012). Studies in positive psychology have focused on topics such as hope, wisdom, optimism, happiness, and gratitude; aspects that lead to thriving on an individual, interpersonal and social level, essential in the promotion of positive aspects of personality (Scorsolini-Comin et al., 2013). With this, gratitude is the subject of interest in the present study. Gratitude has found to contribute to the development of prosocial behaviours and strengthening interpersonal relationships (Emmons \& McCullough, 2004; Peterson \& Seligman, 2012).

According to Emmons and McCullough (2003) and Wood, Joseph, and Maltby (2008) gratitude is a general tendency of an individual to recognize the role of other people, situation, and deity in person's positive outcomes and achievement as well as allowing the individual to respond to such benevolence from particular situations with grateful emotion (Emmons \& McCullough, 2003; Layous et al., 2017). However, researchers have conceptualized gratitude in various ways, for example as a resource of character strength (Peterson \& Seligman, 2012), protective factors (Bartlett \& DeSteno, 2006), moral affect (McCullough et al., 2001) and an affective trait (Paludo \& Koller, 2006). Interestingly, grateful people experience an increased level of happiness (Nezlek, Newman, \& Thrash, 2017), positive emotion (Watkins, Woodward, Stone, \& Kolts, 2003), life satisfaction (Sheldon \& Lyubomirsky, 2006; Wood et al., 2008) and boost well-being. According to (Watkins, Uhder, \& Pichinevskiy, 2015) found that the process of how gratitude influences increase wellbeing occurs through the evocation of positive memories.

To measure gratitude McCullough, Emmons, and Tsang (2002) developed the Gratitude Questionnaire (GQ-6) that measures dispositional gratitude. The GQ-6 has six items assessed via 7 points Likert type scale ranging from 1 (strongly disagree) to 7 (strongly agree). The GQ-6 can facilitate researchers to conduct a large-scale survey. McCullough and his colleagues (2002) have shown that the scores from this scale were both valid and reliable in university students and adults. The confirmatory factor analysis (CFA) showed the robustness of one-factor structure of the GQ-6.

There have been attempts to adapt GQ-6, for example, in Taiwan (Chen, Chen, Kee, \& Tsai, 2009), Spain (Magallares, Recio, \& Sanjuán, 2018), Philippines (Valdez, Yang, \& Datu, 2017), China (Zeng, Ling, Huebner, He, \& Lei, 2017) and Turkey (Yüksel \& Oguz Duran, 2012) reported psychometric evidence identifying one-factor solution composed by five items with satisfactory Cronbach alpha coefficients $(\alpha=$ $.80, .81, .81, .77$ and .74 respectively). Also, (Gouveia et al., 2019) verified in Brazil, a factor structure composed of six items and acceptable internal consistency $(\alpha=.71)$ corroborating the findings of the original study. Moreover, researchers like (Kong, You, \& Zhao, 2017) in China, (Jans-Beken, Lataster, Leontjevas, \& Jacobs, 2015) in Chile and (Langer, Ulloa, Aguilar-Parra, Araya-Véliz, \& Brito, 2016) in Spain adapted the GQ-6 and noted a one-factor model composed of the six original items, showing 
good reliability ( $\alpha=.75, .87, .83$ respectively) and confirmed measurement invariance across gender.

With all the reports, gratitude is an essential tool for assessment and intervention to promote healthy psychological adjustment (Meyers, van Woerkom, \& Bakker, 2013) and increase well-being (Donaldson, Dollwet, \& Rao, 2015; Killen \& Macaskill, 2015; Layous et al., 2017; Lin \& Yeh, 2014). Therefore, the use of valid and reliable measure to evaluate gratitude globally is essential. However, the psychometric evidence of GQ- 6 is relatively under-researched in the Philippines (Valdez et al., 2017). Most of the validation studies reported are in western countries, for example, America (Froh et al., 2011), Italy (Caputo, 2016), Brazil (Gouveia et al., 2019), Spain (Langer et al., 2016), Turkey (Yüksel \& Oguz Duran, 2012), and Ecuador (Vélez et al., 2019). We believed the psychometric evidence of this scale might not apply to Eastern countries and collectivist societies. According to Henrich, Heine, and Norenzayan (2010), the generalizability of the GQ-6 in nonwestern countries is problematic.

The goal of this study is to adapt the GQ-6. We focused on developing Filipino version of the GQ-6 using standard back-translation procedure, systematically gathering evidence of its construct validity (i.e., factorial and criterion), and reliability to add to the current literature on gratitude. To gather evidence of predictive validity, we also correlated GQ-6 with life orientation, subjective happiness, and religiosity. Thus, we expected that gratitude positively correlates with life orientation, subjective happiness, and religiosity. Besides, we established measurement invariance in gender using GQ-6 to ensure that gender differences do not affect the way that Filipino men and women interpret gratitude. Thus, we conducted two studies to achieve our goal.

\section{Study 1. GQ-6 in the Philippines: Factorial validity and reliability}

This study is a first attempt to adapt the GQ-6 to the Philippine context. Specifically, we aimed to test its factorial structure, testing the possibility of identifying a one-factor solution. Moreover, we also examined its corresponding reliability.

\section{Method}

\section{Participants}

340 undergraduate students participated in the study from the National Capital Region, Philippines, with a mean age of 20.63 ( $S D=1.63$; ranging from 18 to 27 years old) shown in Table 1 characteristics of participants (study 1). Most of them were female $(62.1 \%)$, single $(100 \%)$, and reporting to be of a socioeconomic lowerclass $(47.4 \%)$. The majority reported they were undertaking courses in Psychology (14.7\%), Computer Engineering (13.2\%), Hotel restaurant management (9.7\%), Financial Management (9.1\%), and Accountancy (6.8\%). This study was a convenience sample, with participants consisting of people present in a classroom who decided to participate voluntarily. 
Table 1

Characteristics of the study sample $1(N=340)$

\begin{tabular}{|l|c|c|}
\hline \multicolumn{1}{|c|}{ Variable } & $n$ & $\%$ \\
\hline Gender & & \\
\hline Male & 129 & 37.9 \\
\hline Female & 211 & 62.1 \\
\hline Age & 184 & 54.1 \\
\hline 20 or below & 153 & 45.0 \\
\hline $21-25$ & 3 & 0.9 \\
\hline 26 or above & & \\
\hline Family monthly income & 161 & 47.4 \\
\hline P20,000 or below & 29 & 8.5 \\
\hline P20,001-30,000 & 36 & 10.6 \\
\hline P30,001-40,000 & 6 & 1.8 \\
\hline P40,001-50,000 & 1 & 0.3 \\
\hline P50,001-60,000 & 74 & 21.8 \\
\hline P60,001-70,000 & 33 & 9.7 \\
\hline P70,001 or above & & \\
\hline Academic program & 5 & 1.5 \\
\hline English language studies & 7 & 2.1 \\
\hline Elementary Education & 23 & 6.8 \\
\hline Accountancy & 19 & 5.6 \\
\hline Architecture & 31 & 9.1 \\
\hline Financial Management & 11 & 3.2 \\
\hline Civil Engineering & 13 & 3.8 \\
\hline Dentistry & 45 & 13.2 \\
\hline Computer Engineering & 21 & 6.2 \\
\hline Marketing Management & 17 & 5.0 \\
\hline Mechanical Engineering & 22 & 6.5 \\
\hline Medical Technology & 20 & 5.9 \\
\hline Nursing & 33 & 14.7 \\
\hline Psychology & & 1.5 \\
\hline Tourism Management & 5.3 \\
\hline Electrical Engineering & 9.7 \\
\hline Hotel Restaurant Management & \\
\hline
\end{tabular}

\section{Instruments}

a) Demographic data questionnaire ad hoc. Participants completed a questionnaire investigating their demographic characteristics (sex, age, educational level, marital status, and family monthly income).

b) Gratitude Questionnaire (GQ-6; McCullough, Emmons, \& Tsang, 2002). This questionnaire is composed of six items (e.g., "I have so much in life to be thankful for," "If I would list everything that I felt grateful for, it would be a very long list," "I am grateful to a wide variety of people"), assessing the tendency to experience gratitude in everyday life. The responses were given as a 7-point scale, ranging from 1 (strongly disagree) to 7 (strongly agree). The 
Filipino translation of the GQ-6 was produced using the back-translation procedure, collaborating on this task to a Filipino bilingual researcher and validated by the Commission on the Filipino Language. In order to verify the semantic validity of the instrument, a group composed of ten participants from the target population answered the questionnaire. We aimed to check if the instructions were sufficient, if the items were readable, and whether they could be answered according to the proposed response scale. Modifications were not necessary, resulting in the final version of this measure.

\section{Procedure}

Participants took part in the present study by completing a questionnaire in the collective context of the classroom. The first page of the survey form contained information regarding the goal of the study and oriented instructions on how to answer the questionnaire. All participants were informed that the study was voluntary, and no provided monetary reward. The Ethics Committee has approved the research project from a private university in Manila, Philippines. On average, the participants required 10 minutes to complete the questionnaire.

\section{Data analysis}

Analyzing the psychometric properties of the GQ-6 scale was performed to determine the validity and reliability of the instrument in the Filipino sample. An exploratory factor analysis (EFA) using principal component analysis applied in the Filipino validation of the GQ-6, parallel analyses were conducted to determine the number of factors to retain in the EFA (Jans-Beken et al., 2015). Cronbach $\alpha$ 's was calculated to determine the reliability of the GQ-6. The SPSS v.24 performed for all statistical analysis.

\section{Results}

the first stage, data demonstrated appropriate for performing $\mathrm{EFA}(\mathrm{KMO}=.83$ and Bartlett's Sphericity Test, $\left.\chi^{2}[15]=563.108, p<.001\right)$. Regarding the dimensionality of the instrument, the data suggests a one-factor solution (eigenvalue $=3.05$ ) explained $50.84 \%$ of the variance of the instrument. The commonalities of the items varied from 0.39 (item 6) to 0.57 (item 1) and found to be adequate. The corresponding structure of the GQ-6 is presented in Table 2.

As shown in Table 2, for the observed one-factor solution, the results indicated satisfactory evidence of the construct (factorial) validity of the GQ-6. All six items presented loadings above 0.40 on the general factor of gratitude, ranging from 0.62 (Item 6. Long amounts of time can go by before I feel grateful to something or someone) to 0.76 (Item 5. As I get older, I find myself more able to appreciate people, events, and situations that have been part of my life history). Moreover, the internal consistency coefficient (Cronbach's $\alpha$ ) was .81.

In sum, these are the findings regarding the GQ-6 in the Philippines, showing evidence for the one-factor structure, revealing adequate evidence internal 
consistency. However, we did not perform the CFA because the sample size is only sufficient for the EFA (Tabachnick, Fidell, \& Ullman, 2007). It is essential to replicate the results, conduct further validation as well as offering additional evidence of the psychometric appropriateness of this measure, as indicated in the next study.

Table 2

Factor structure of the Gratitude Questionnaire (GQ-6)

\begin{tabular}{|c|c|c|}
\hline \multicolumn{1}{|c|}{ Items } & Loadings & $\eta^{2}$ \\
\hline $\begin{array}{l}\text { 5. As I get older I find myself more able to appreciate people, } \\
\text { events and situations that have been part of my life history } \\
\text { (Habang tumatanda ako, higit kong ipinagpapasalamat ang mga } \\
\text { tao, pangyayari, at pangyayaring naging bahagi ng aking buhay) }\end{array}$ & 0.76 & 0.57 \\
\hline $\begin{array}{l}\text { 1. I have so much in life to be thankful for } \\
\text { (Maraming bagay sa aking buhay na dapat kong ipagpasalamat) }\end{array}$ & 0.75 & 0.57 \\
\hline $\begin{array}{l}\text { 4. I am grateful to a wide variety of people } \\
\text { (Nagpapasalamat ako sa ibat-ibang klase ng tao) }\end{array}$ & 0.73 & 0.53 \\
\hline $\begin{array}{l}\text { 2. If I would list everything that I felt grateful for, it would be a } \\
\text { very long list } \\
\text { (Kung ililista ko ang mga bagay na dapat kong ipagpasalamat, } \\
\text { mahabang listahan ito) }\end{array}$ & 0.73 & 0.53 \\
\hline $\begin{array}{l}\text { 3. When I look at the world, I don't see much to be grateful for } \\
\text { (Sa tuwing nagninilay-nilay ako, wala akong masyadong maisip } \\
\text { na dapat kong ipagpasalamat) }\end{array}$ & 0.68 \\
\hline $\begin{array}{l}\text { 6. Long amounts of time can go by before I feel grateful to } \\
\text { something or someone } \\
\text { (Matagal bago ko maramdaman ang pasasalamat sa isang bagay } \\
\text { o tao) }\end{array}$ & 0.62 \\
\hline
\end{tabular}

\section{Study 2. GQ-6 in the Philippines: Confirmatory factor analysis, reliability, and criterion validity}

The present study attempted to confirm the one-factor structure of the GQ-6 in an independent sample, in addition to gathering evidence of its criterion validity regarding measures focusing on the orientation of life and well-being.

\section{Method}

\section{Participants}

813 undergraduate students participated in the study from the National Capital Region, Philippines, with a mean age of 19.99 years $(S D=1.85 ; 18-29$ years old). Most of them were male $(50.1 \%)$, single $(100 \%)$, and reporting to be of a socioeconomic lower-class $(22.9 \%)$. The majority reported they were undertaking courses in Architecture (18.9\%), Computer Engineering (12.4\%), Accountancy (11.8\%), Dental Medicine (10.8\%). This study was a convenience sample (Table 3). 
Table 3

Characteristics of the study sample $2(N=813)$

\begin{tabular}{|c|c|c|}
\hline Variable & $n$ & $\%$ \\
\hline \multicolumn{3}{|l|}{ Sex } \\
\hline Male & 407 & 50.1 \\
\hline Female & 406 & 49.9 \\
\hline \multicolumn{3}{|l|}{ Age } \\
\hline 20 or below & 500 & 61.5 \\
\hline $21-25$ & 309 & 38.0 \\
\hline 26 or above & 4 & 0.5 \\
\hline \multicolumn{3}{|l|}{ Family monthly income } \\
\hline P20,000 or below & 154 & 18.9 \\
\hline P20,001-30,000 & 186 & 22.9 \\
\hline$P 40,001-50,000$ & 93 & 11.4 \\
\hline$P 60,001-70,000$ & 156 & 19.2 \\
\hline P70,000 or above & 224 & 27.6 \\
\hline \multicolumn{3}{|l|}{ Academic programs } \\
\hline Secondary Education & 14 & 1.7 \\
\hline Elementary Education & 13 & 1.6 \\
\hline Psychology & 5 & 0.6 \\
\hline Physical Education & 25 & 3.1 \\
\hline Accountancy & 96 & 11.8 \\
\hline Financial Management & 22 & 2.7 \\
\hline Marketing Management & 37 & 4.6 \\
\hline Accounting Information System & 13 & 1.6 \\
\hline Architecture & 154 & 18.9 \\
\hline Dental Medicine & 88 & 10.8 \\
\hline Civil Engineering & 70 & 8.6 \\
\hline Environmental Sanitary Engineering & 27 & 3.3 \\
\hline Electrical Engineering & 56 & 6.9 \\
\hline Computer Engineering & 101 & 12.4 \\
\hline Electronics Engineering & 14 & 1.7 \\
\hline Mechanical Engineering & 35 & 4.3 \\
\hline Pharmacy & 15 & 1.8 \\
\hline Medical Technology & 20 & 2.5 \\
\hline Nursing & 8 & 1.0 \\
\hline
\end{tabular}

Instruments

a) Demographic data questionnaire ad hoc. Participants completed a questionnaire investigating their demographic characteristics (sex, age, educational level, marital status, and family monthly income).

b) Life Orientation Test-Revised (LOT-R; Scheier, Carver, \& Bridges, 1994). The LOT$\mathrm{R}$ measures dispositional optimism. It is composed of 10 items (Cronbach $\alpha=$ .90) (e.g., "In uncertain times, I usually expect the best," "It's easy for me to relax," "I enjoy my friends a lot"). These items were answered using a 5-point scale, ranging from 1 (/ agree a lot) to 5 (/ disagree a lot). Items 2,5, 6, and 8 
are fillers. Responses to items 3, 7, and 9 are reverse scored. A higher scores on LOT-R imply optimism.

c) Subjective Happiness Scale (SHS; Lyubomirsky \& Lepper, 1999). The SHS assess the subjective happiness. It is composed of 4 items (Cronbach $\alpha=.82$ ) (e.g., "In general, I consider myself," "Compared to most of my peers, I consider myself," "Some people are generally very happy"). These items were answered using a 7 -point scale, ranging from 1 (not a very happy person) to 7 (very happy person). Items 1, 2, 3 are positive items. Responses to item 4 are reverse scored. A higher scores on SHS imply higher subjective happiness.

d) Spirituality/Religiousness (SPI) revised International Personality Item Pool-Values in Action (VIA; Peterson \& Seligman, 2012). The SPI assess religiosity of an individual. The revised SPI is composed of 9 items (Cronbach $\alpha=.84$ ) (e.g., "Am spiritual person," "Keep my faith even during hard times," "Prayer or meditation"). These items were answered using a 5-point scale, ranging from 1 (very much unlikely me) to 5 (very much likely me). The items 1, 2, 3, 4, 5, 6, and 7 are positive items. Responses to items 8 and 9 are reverse scored. A higher scores on SPI imply higher spiritual/religious.

\section{Procedure}

Participants took part in the present study by completing a questionnaire in the collective context of the classroom. The participants recruited in the study 2 are not included in the study 1 . The first page of the survey form contained information regarding the goal of the study and oriented instructions on how to answer the questionnaire. All participants were informed that the study was voluntary, and no monetary reward. The Ethics Committee has approved the research project from a private university in Manila, Philippines. On average, the participants required 15 minutes to complete the questionnaire.

\section{Data analyses}

At first, we conducted a confirmatory factor analysis and checked goodnessof-fit indices and factor loadings to examine the one-factor structures of original scales using Amos v.21. The Mardia's coefficients for multivariate kurtosis were $>3$, indicating significant multivariate non-normality in our data. Therefore, we used the Bollen-Stine bootstrap procedures (2,000 samples) with Maximum Likelihood (ML) estimation to accommodate the lack of multivariate normality. Because $\chi^{2}$ is sensitive to sample size, the following indices were used to evaluate the model's goodness of fit: non-normal fit index (NNFI), comparative fit index (CFI), standardized root mean square residual (SRMR), and root mean square error of approximation (RMSEA). By convention, the fit was considered acceptable when NNFI and CFI > .90, RMSEA < .10, SRMR $<0.05(\mathrm{Hu} \&$ Bentler, 1999). The Pearson moment correlation was computed to provide evidence on the validity of the GQ-6 on three scales measures of optimism, subjective happiness, and religiosity. The Cronbach $\alpha$ was calculated to determine the reliability of the scale. We also tested whether gratitude would have the same meaning across gender through multi-group CFA. In particular, we 
examined the following degree of invariance was achieved: a) configural invariance (equal number of factors and pattern-indicator loading); b) metric invariance (equal factor loading); c) scalar invariance (equal factor variance and covariance); and d) residual variance invariance (equal error variance and covariance). According to (Chen, 2007) the invariance was met if the changes in RMSEA is lower than .01.

\section{Results}

The CFA analysis indicated that all the fit indices of the model, except RMSEA, meet their corresponding criteria, $\chi^{2}(9)=130.43, p<.001, N N F I=0.92, C F I=.93$, $\mathrm{RMSEA}=.12, \mathrm{SRMR}=0.03$. Therefore, the proposed model provided an acceptable fit to the data. Consequently, to improve the model, the modification indices were examined. Item 1 ("I have so much in life to be thankful for") and item 2 ("If I would list everything that I felt grateful for, it would be a very long list") reflect gratitude span, so we allowed errors of these two items to correlate. The results found that the model showed a better fit to the data, $\chi^{2}=39.34, p<.01, \mathrm{NNFI}=0.98, \mathrm{CFI}=.98$, $\mathrm{RMSEA}=.05, \mathrm{SRMR}=0.01$. The factor loadings ranged from 0.53 to 0.75 (Figure 1). The scale also had good Cronbach's reliability coefficient $(\alpha=.84)$. Table 4 shows the descriptive statistics and reliability coefficient of the scale.

Figure 1

Factor structure of the Gratitude Questionnaire (GQ-6)

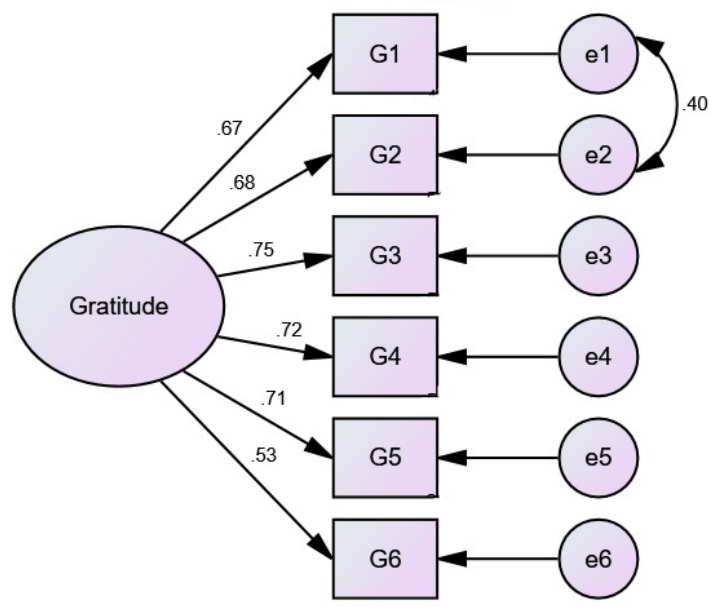

Table 4

Descriptive statistics and reliability coefficients of the scales

\begin{tabular}{|l|c|c|c|}
\hline \multicolumn{1}{|c|}{ Variable } & Cronbach's alpha & $M$ & $S D$ \\
\hline Gratitude & .84 & 5.95 & 0.55 \\
\hline Life Orientation & .90 & 3.65 & 0.66 \\
\hline Subjective happiness & .82 & 5.47 & 0.66 \\
\hline Religiosity & .80 & 3.47 & 0.66 \\
\hline
\end{tabular}


In addition to previous findings, we looked for observable evidence of the criterion validity of this questionnaire regarding three scales assessing life orientation, subjective happiness and religiosity. We expected people higher in gratitude to show an optimistic attitude towards life. Our findings corroborated such association $(p<.001)$, indicating that gratitude scores were positively correlated with life orientation ( $r=.29)$, subjective happiness $(r=.08)$, and religiosity $(r=.31)$. These findings offered evidence of its criterion validity concerning factors assessing life orientation and well-being.

Multi-group CFA was carried out to test the configural invariance model in which the GQ-6 has a one-factor structure across groups. The results demonstrated that the scores from the 6-item of the gratitude questionnaire exhibited configural, metric, scalar, and residual variance invariance as the differences in RMSEA ( $\triangle$ RMSEA) were less than .01. See Table 5 measurement invariance of the GQ-6 across gender.

Table 5

Measurement invariance of the Gratitude Questionnaire (GQ-6) across gender

\begin{tabular}{|c|c|c|c|c|c|c|c|c|c|}
\hline \multirow{2}{*}{ Model } & \multirow{2}{*}{$\chi^{2}$} & \multirow{2}{*}{$d f$} & \multirow{2}{*}{$p$} & \multirow{2}{*}{$\mathrm{CFI}$} & \multirow{2}{*}{ GFI } & RMSEA & \multirow{2}{*}{$\Delta \chi^{2}$} & \multirow{2}{*}{$\Delta \mathrm{CFI}$} & \multirow{2}{*}{$\triangle \mathrm{RMSEA}$} \\
\hline & & & & & & $(90 \% \mathrm{Cl})$ & & & \\
\hline M1: Configural & 49.02 & 16 & $<.01$ & .98 & .98 & $.05(.03-.07)$ & -- & -- & -- \\
\hline M2: Metric & 60.97 & 21 & $<.001$ & .978 & .977 & $.048(.03-.06)$ & 11.95 & .003 & .002 \\
\hline M3: Scalar & 63.55 & 22 & $<.001$ & 977 & .976 & $.048(.03-.06)$ & 2.58 & .001 & .00 \\
\hline Residual variance & 101.84 & 29 & $<.001$ & .96 & .96 & $.056(.04-.07)$ & 38.29 & 017 & .008 \\
\hline
\end{tabular}

\section{Discussion}

The current study aimed to examine the validity of the Filipino version of the GQ-6 and measurement invariance across sex in Filipino college students. Hence, to evaluate the factor structure of the GQ-6, two independent studies were conducted. Study 1 carry out exploratory factor analysis using subset samples, observing results consistent with the original English version of the GQ (McCullough et al., 2002). The Filipino GQ showed good internal consistency reliability $(\alpha>$.70) (Cohen, Swerdlik, \& Sturman, 2014). Moreover, consistent with the English GQ (McCullough et al., 2002), the EFA yielded a one-factor structure, with an adequate model fit (JansBeken et al., 2015).

Study 2 carryout confirmatory factor analysis using an independent subset sample, confirming the unidimensionality structure of the six-item gratitude scale, presenting an acceptable index of reliability. The goodness of fit indexes was in line with the recommended in the literature (Hu and Bentler, 1999). In turn, the present findings of the study supported existing evidence on the validity of gratitude questionnaire in collectivist societies (Chen et al., 2009; Kong et al., 2017; Valdez et al., 2017; Zeng et al., 2017; Futoshi, 2013) using the original version of GQ-6. For the criterion validity, we tested the association of gratitude with life orientation, subjective happiness, and religiosity. The Filipino GQ could be significantly associated 
with life orientation, subjective happiness, and religiosity, similar with the findings in previous studies (Aghababaei, Błachnio, \& Aminikhoo, 2018; Chen et al., 2009; Gruszecka, 2015; Kraus, Desmond, \& Palmer, 2015; Witvliet et al., 2019). These results suggest that gratitude is a necessary character strength for achieving a healthy life.

Our study also demonstrated that the scores from GQ- 6 were invariant across gender which corroborated the results in the previous investigation (Langer et al., 2016; Valdez et al., 2017; Zeng et al., 2017). This invariance indicates gratitude may hold similar meaning for boys and girls in collectivist context.

The present study contributes to the study of gratitude. This study is an attempt to measure gratitude using a short questionnaire with adequate psychometric properties. However, we observed potential limitations. First, the samples used in this study are non-probability and limited to college students; the generalizability of these results beyond the present sample is inadequate. Secondly, the completion of the survey is limited to college sample. Thus, future study is still required considering participants from a general and clinical population. Intriguingly, older and more educated people are more grateful for their lives (Jans-Beken et al., 2015). We also recommend including people of different age groups are necessary to address issues in the generalizability of the findings. Third, the present study failed to test other types of validity, such as discriminant and concurrent validity. Therefore, future studies could collect additional data in order to provide further evidence for the suitability of the GQ-6 in the Philippines. Future studies may check evidence of convergent validity (i.e., big five personality), concurrent validity (i.e., materialism, depression, and anxiety), predictive validity (i.e., resilience in life, lower stress level indicated in cortisol) and convergent validity (i.e., subjective well-being).

In conclusion, the results of the present study indicated that the one-factor with six items model of the GQ possessed a satisfactory factorial validity invariant across Filipino college students. Furthermore, the GQ-6 correlates with several theoretical related constructs, which further supports its construct validity.

\section{References}

Aghababaei, N., Błachnio, A., \& Aminikhoo, M. (2018). The relations of gratitude to religiosity, well-being, and personality. Mental Health, Religion \& Culture, 21(4), 408417. doi: 10.1080/13674676.2018.1504904

Bartlett, M. Y., \& DeSteno, D. (2006). Gratitude and prosocial behavior: Helping when it costs you. Psychological Science, 17(4), 319-325.

Caputo, A. (2016). Italian translation and validation of the GQ-6. International Journal of Wellbeing, 6(2), 80-92. doi: 10.5502/jww..v6i2.492.

Chen, F. F. (2007). Sensitivity of goodness of fit indexes to lack of measurement invariance. Structural Equation Modeling: A Multidisciplinary Journal, 14(3), 464-504.

Chen, L. H., Chen, M.-Y., Kee, Y. H., \& Tsai, Y.-M. (2009). Validation of the Gratitude Questionnaire (GQ) in Taiwanese undergraduate students. Journal of Happiness Studies, 10(6), 655.

Cohen, R. J., Swerdlik, M. E., \& Sturman, E. D. (2014). Testagem e avaliação psicológica: Introdução a testes e medidas [Psychological testing and assessment: Introduction to tests and measures]. Porto Alegre: AMGH Editora Ltda. 
Donaldson, S. I., Dollwet, M., \& Rao, M. A. (2015). Happiness, excellence, and optimal human functioning revisited: Examining the peer-reviewed literature linked to positive psychology. The Journal of Positive Psychology, 10(3), 185-195.

Emmons, R. A., \& McCullough, M. E. (2003). Counting blessings versus burdens: an experimental investigation of gratitude and subjective well-being in daily life. Journal of personality and social psychology, 84(2), 377-389.

Emmons, R. A., \& McCullough, M. E. (2004). The psychology of gratitude. New York, NY: Oxford University Press.

Futoshi, K. (2013). Development and validation of the Gratitude Questionnaire (GQ) in Japanese undergraduate students. Comparative Culture, the Journal of Miyazaki International College, 18, 2-19.

Fredrickson, B. L. (2000). Cultivating positive emotions to optimize health and well-being. Prevention \& treatment, 3(1), 1 a.

Fredrickson, B. L. (2001). The role of positive emotions in positive psychology: The broadenand-build theory of positive emotions. American Psychologist, 56(3), 218.

Froh, J. J., Fan, J., Emmons, R. A., Bono, G., Huebner, E. S., \& Watkins, P. (2011). Measuring gratitude in youth: Assessing the psychometric properties of adult gratitude scales in children and adolescents. Psychological Assessment, 23(2), 311.

Gouveia, V. V., Ribeiro, M. G. C., de Aquino, T. A. A., Loureto, G. D. L., Nascimento, B. S., \& Rezende, A. T. (2019). Gratitude Questionnarie (GQ-6): Evidence of construct validity in Brazil. Current Psychology, 1-9.

Gruszecka, E. (2015). Appreciating gratitude: Is gratitude an amplifier of well-being? Polish Psychological Bulletin, 46(2), 186-196. doi: 10.1515/ppb-2015-0025.

Henrich, J., Heine, S. J., \& Norenzayan, A. (2010). Most people are not WEIRD. Nature, 466(7302), 29-29.

Hu, L., \& Bentler, P. M. (1999). Cutoff criteria for fit indexes in covariance structure analysis: Conventional criteria versus new alternatives. Structural Equation Modeling, 6, 1-55. doi: 10.1080/10705519909540118.

Jans-Beken, L., Lataster, J., Leontjevas, R., \& Jacobs, N. (2015). Measuring gratitude: A comparative validation of the Dutch Gratitude Questionnaire (GQ6) and short gratitude, resentment, and appreciation test (SGRAT). Psychologica Belgica, 55(1), 19.

Killen, A., \& Macaskill, A. (2015). Using a gratitude intervention to enhance well-being in older adults. Journal of Happiness Studies, 16(4), 947-964.

Kong, F., You, X., \& Zhao, J. (2017). Evaluation of the Gratitude Questionnaire in a Chinese sample of adults: Factorial validity, criterion-related validity, and measurement invariance across sex. Frontiers in psychology, 8, 1498.

Kraus, R., Desmond, S. A., \& Palmer, Z. D. (2015). Being thankful: Examining the relationship between young adult religiosity and gratitude. Journal of Religion and Health, 54(4), 1331-1344. doi: 10.1007/s10943-014-9923-2

Langer, Á. I., Ulloa, V. G., Aguilar-Parra, J. M., Araya-Véliz, C., \& Brito, G. (2016). Validation of a Spanish translation of the Gratitude Questionnaire (GQ-6) with a Chilean sample of adults and high schoolers. Health and quality of life outcomes, 14(1), 53.

Layous, K., Sweeny, K., Armenta, C., Na, S., Choi, I., \& Lyubomirsky, S. (2017). The proximal experience of gratitude. PloS one, 12(7), e0179123.

Lin, C.-C., \& Yeh, Y.-c. (2014). How gratitude influences well-being: A structural equation modeling approach. Social indicators research, 118(1), 205-217.

Lyubomirsky, S., \& Lepper, H. S. (1999). A measure of subjective happiness: Preliminary reliability and construct validation. Social indicators research, 46(2), 137-155.

Magallares, A., Recio, P., \& Sanjuán, P. (2018). Factor structure of the Gratitude Questionnaire in a Spanish sample. The Spanish journal of psychology, 21. 
McCullough, M. E., Emmons, R. A., \& Tsang, J.-A. (2002). The grateful disposition: A conceptual and empirical topography. Journal of Personality and Social Psychology, 82(1), 112.

McCullough, M. E., Kilpatrick, S. D., Emmons, R. A., \& Larson, D. B. (2001). Is gratitude a moral affect? Psychological Bulletin, 127(2), 249.

Meyers, M. C., van Woerkom, M., \& Bakker, A. B. (2013). The added value of the positive: A literature review of positive psychology interventions in organizations. European Journal of Work and Organizational Psychology, 22(5), 618-632.

Nezlek, J. B., Newman, D. B., \& Thrash, T. M. (2017). A daily diary study of relationships between feelings of gratitude and well-being. The Journal of Positive Psychology, 12(4), 323-332.

Paludo, S. d. S., \& Koller, S. H. (2006). Gratidão em contextos de risco: uma relação possível? [Gratitude on adversity contexts: is it possible a relationship?]. Psicodebate, 7, 55-66.

Peterson, C., \& Seligman, M. E. (2012). Character Strengths and Virtues: A handbook and classification vol. 1. Oxford University Press.

Scheier, M. F., Carver, C. S., \& Bridges, M. W. (1994). Distinguishing optimism from neuroticism (and trait anxiety, self-mastery, and self-esteem): A reevaluation of the Life Orientation Test. Journal of Personality and Social Psychology, 67(6), 1063.

Scorsolini-Comin, F., Fontaine, A. M. G. V., Koller, S. H., \& Santos, M. A. d. (2013). From authentic happiness to well-being: The flourishing of positive psychology. Psicologia: Reflexão e Crítica, 26(4), 663-670.

Seligman, M. E. (2012). Flourish: A visionary new understanding of happiness and well-being: Simon and Schuster.

Seligman, M. E., \& Csikszentmihalyi, M. (2014). Positive psychology: An introduction. In Flow and the foundations of positive psychology (pp. 279-298). Dordrecht: Springer.

Sheldon, K. M., \& Lyubomirsky, S. (2006). How to increase and sustain positive emotion: The effects of expressing gratitude and visualizing best possible selves. The Journal of Positive Psychology, 1(2), 73-82.

Tabachnick, B. G., Fidell, L. S., \& Ullman, J. B. (2007). Using multivariate statistics (Vol. 5). Boston, MA: Pearson.

Valdez, J. P. M., Yang, W., \& Datu, J. A. D. (2017). Validation of the Gratitude Questionnaire in Filipino secondary school students. The Spanish Journal of Psychology, 20. doi: 10.1017/sjp.2017.51

Vélez, M. C., Castro, S. L., Contreras, E. P., Sizer, M. A., Pacheco, A. B., \& Medina, P. A. (2019). Adaptation and validation of the Gratitude Questionnaire GQ-6 for the Ecuadorian context. Avaliaçao Psicologica: Interamerican Journal of Psychological Assessment, 18(2), 129-137.

Watkins, P. C., Uhder, J., \& Pichinevskiy, S. (2015). Grateful recounting enhances subjective well-being: The importance of grateful processing. The Journal of Positive Psychology, 10(2), 91-98.

Watkins, P. C., Woodward, K., Stone, T., \& Kolts, R. L. (2003). Gratitude and happiness: Development of a measure of gratitude, and relationships with subjective well-being. Social Behavior and Personality: An International Journal, 31(5), 431-451.

Witvliet, C. v., Richie, F. J., Root Luna, L. M., \& Van Tongeren, D. R. (2019). Gratitude predicts hope and happiness: A two-study assessment of traits and states. The Journal of Positive Psychology, 14(3), 271-282. doi: 10.1080/17439760.2018.1424924

Wood, A. M., Joseph, S., \& Maltby, J. (2008). Gratitude uniquely predicts satisfaction with life: Incremental validity above the domains and facets of the five factor model. Personality and Individual Differences, 45(1), 49-54.

Yüksel, A., \& Oguz Duran, N. (2012). Turkish adaptation of the Gratitude Questionnaire. Eurasian Journal of Educational Research, 46, 199-215. 
Zeng, Y., Ling, Y., Huebner, E. S., He, Y., \& Lei, X. (2017). The psychometric properties of the 5-item Gratitude Questionnaire in Chinese adolescents. Journal of Psychiatric and Mental Health Nursing, 24(4), 203-210. doi: 10.1111/jpm.12372

RECEIVED: January 15, 2021

ACCEPTED: June 12, 2021 